\title{
Implications of Non -productive and Productive Government Expenditure on Output and Employment: Evidence From Nigeria
}

\author{
Abiola John Asaleye ${ }^{1}$, Rotdelmwa Filibus Maimako ${ }^{2}$, Henry Inegbedion ${ }^{3}$, Adedoyin Isola Lawal ${ }^{4} \&$ Charity O. \\ $\mathrm{Aremu}^{5}$ \\ ${ }^{1}$ Economics Department, Landmark University, Nigeria \\ ${ }^{2}$ College of Sciences, Landmark University, Nigeria \\ ${ }^{3}$ Business Administration Department, Landmark University, Nigeria \\ ${ }^{4}$ Banking and Finance Department, Landmark University, Nigeria \\ ${ }^{5}$ Department of Crop and Social Sciences, Landmark University, Nigeria
}

Correspondence: Abiola John Asaleye, Economics Department, Landmark University, Nigeria. E-mail: asaleye.abiola@lmu.edu.ng

Received: May 24, 2020

Accepted: July 15, 2020

Online Published: January 11, 2021

doi:10.5430/rwe.v12n2p51

URL: https://doi.org/10.5430/rwe.v12n2p51

\begin{abstract}
Nigerian government expenditure has been on an increasing trend over the years, and its contribution to sustainable economic development; promoting long-term output and employment has generated controversial issues in the literature. Against this background, this study analyses the impact of both productive and non-productive government expenditure on output and employment in Nigeria using the Vector Error Correction Model, The long-run equations for output and employment are established. The joint short and long-run causality was also investigated. The study shows a contrary result to theoretical predictions; Nigeria's long-run growth is not promoting by productive government expenditure. Furthermore, there is joint short and long-run causality between employment and government expenditure channels. Evidence from the output equation indicates no joint long and short-run causality. The implication of this result shows that government expenditure either productive or non-productive, has not improved the economy, although there is an increase in employment generation through the non-productive channel, which has not promoted broad-based growth. For the Nigerian government to improve the situation, the study recommends a critical assessment of public expenditure through the cost-benefit approach.
\end{abstract}

Keywords: government expenditure, employment, output, long-run

\section{Introduction}

The consensus of capital to propel growth and development is well documented in the literature. Strand of the literature has shown that capital accumulation is vital to promote growth and development (Popoola, Alege, Gershon \& Asaleye, 2019; Oladipo, Iyoha, Fakile, Asaleye \& Eluyela, 2019a; Cyrenne \& Pandey, 2015). Most empirical studies, refer to the output model, where capital and labour are used as inputs requirements to increase aggregate output. Due to the low rate of investment in most developing economies, government expenditure covers most aspects of the economy in boosting research and development, investment on fixed assets, payment of wages, and salaries. Despite the huge amount of government expenditure, the economy still grows at a slow pace in African countries compare to other regions, especially in Nigeria (Asaleye et al., 2019). The slow pace of growth in the economy may be attributed to different factors such as mismanagement of resources, political instability, and instability in the northern part of the country caused by terrorism and others (Aremu et al., 2019). However, studies have stressed the importance of distinguishing between productive and non-productive government expenditure to maximise public expenditure on the economy (Blanchard, 2010; Katema. 2000; Barro, 1990).

Consequently, the study by Devarajan, Swaroop and Zou (1996) classified government expenditure into two, namely productive expenditure and non-productive expenditure. A recent study by Chu, Holscher and McCarthy (2020) investigate how productive and non-productive government expenditure affect economic growth in high-income and middle -income economies. The scholars reported that diverting government expenditure from non-productive to productive channels would improve growth both in the short and long-run. Similarly, Glomm \& Ravikummmar 
(1997) also show that productive government expenditure has a long-run positive impact on growth in America. However, considering how government expenditure affects the economy, mixed results are documented in the literature (Gemmell et al. 2016; Afonso \& Gonzalez-Alegre, 2011; Christe, 2012; Moreno-Dodson, 2008), show the positive and negative influences of government expenditure on the economy. One of the notable factors for the variation of results is that most of these studies are carried out using cross-country data. Fashina, Asaleye, Ogunjobi and Lawal (2018) stressed that cross-country analysis might result in unbiased outcome due measurement and specification error. Besides, different countries have dissimilarities in the growth process, which might be generalised to be the same in most of these cross analyses.

Theoretically, there is no consensus on the implications of capital accumulation on both developed and developing economies. The neoclassical holds that economic growth depends on the accumulation of labour, capital and technological growth. The theory emphasises on capital accumulation. The theory holds that a country accumulating capital more rapidly will grow faster than the one whose accumulation is slower (Asaleye et al., 2020; Blanchard, 2011). The neoclassical growth model, as developed by Solow (1956) and Swan (1956) popularly known as Solow-Swan (1956) growth model, assumes that the productivity of the production inputs of capital and labour are subject to diminishing returns.

Contrary to the former's outcome, for instance, if a country accumulates more capital inputs, the marginal product of capital (MPC) will reduce; this means that a country with abundant capital will have a slower growth rate than a country that is poor in capital. Given this scenario, countries with lower capital will grow much faster as they accumulate capital than capital-rich countries; this suggests countries' capital theory converging as they develop, as richer countries grow slower while poorer countries grow faster. However, government expenditure on research and development and education play an important role in capital accumulation. Diamond (1965) stressed the importance of investment through capital accumulation on aggregate output. Barro and Sila - I - Martin (1990) pointed out that private investment promotes growth; while Barro (1990) in his classification of public expenditure stressed that 'unproductive government expenditure' may have an adverse effect on the economy. In a similar study, Katema (2000) reported that capital formation increases labour productivity via increases in skills and health. Blanchard (2010)'s study shared the same perspective with the outcome of the study of Katema (2000).

However, the output model by Solow (1956) and Swan (1956) has many analytical misconceptions. The idea that countries will grow and reach the point of saturation does not agree with the real world, given the developed economies' present situation. Likewise, the belief that developing economies will grow faster than the developed economies has not shown reality implications. In addition, technology is not acquired unintentionally as the theory suggested (Sweezey \& MCconaghy, 2011; Popoola, Asaleye \& Eluyela, 2019). The endogenous growth theory holds that economic growth is primarily the result of internal forces within the economy instead of outside forces (Romer, 1994). The endogenous growth theory also states that both positive externalities and spillover effects of the knowledge-based economy contribute to economic growth. The endogenous growth also holds that the long-run growth rate of an economy is a function of government policy measures, which include government expenditure: subsidy on basic research, the quality of education, among others (Oladipo, Iyoha, Fakile, Asaleye \& Eluyela, 2019b; Sweezey \& McConaghy, 2011). In summary, empirical and theoretical literature has shown indecisive outcomes on government expenditure implications on the economy.

In Nigeria, since independence in 1960, the country has witnessed many different regimes, both civilian and military regimes with varying economic policies and programmes for growth and development. These different regimes' economic policies have not yielded the desired result (Adama, Asaleye, Oye \& Ogunjobi, 2018). Empirical studies relating to Nigeria have focused on aggregate public expenditure, capital and recurrent expenditure, and the agricultural sector. With most studies focused on output. One of the main macroeconomic problems, the country faces is the high unemployment rate (Olopade, Okodua, Oladosun, Asaleye, 2019; Aremu 2019). Interesting the study by Popoola, Alege, Gherson and Asaleye (2019) investigate the basic and the advanced channels of human capital on the Nigerian economy, documenting that the advanced channel can promote growth and development, however, the study by Popoola et al. (2019) did not include 'non-productive and productive government expenditure'. This study is distinguished from the above studies by investigating the productive and non-productive public expenditure on output and employment in Nigeria using the Vector Error Correction Model (VECM). We generated two equations to explain the output and employment behaviours by considering the effect of various government expenditure, such as the functioning expenditure, non-productive expenditure, productive expenditure, government expenditure on investment and private investment. This study may benefit other developing economies with a similar structure to Nigeria by instigating the specific channels to maximise government expenditure on the economy. 
The study is structured into four sections. Section 1 is the Introduction, explains the background of the study. Section 2 presents the Material and Method, which describes the study's theoretical framework and model specification. Section 3 introduces the Presentation of Result. Section 4 gives the Conclusion and Recommendation.

\section{Material and Methods}

The theoretical framework of this work uses Diamond (1965) model. In the model, the influence of capital accumulation is emphasised and expressed as follows:

$$
A G C S P=\operatorname{InCSP} t+\alpha \operatorname{InCSP} P_{t-1}
$$

In equation 2.1, AGCSP is the aggregate consumption, expressed as consumption at present (CSP) and consumption at the previous year $\left(\mathrm{CSP}_{\mathrm{t}-1}\right)$. The ' $\mathrm{t}$ ' indicates time and $\alpha$ is the marginal prosperity to consume, ranges from 0 to 1 ; this shows that the consumer or household can live on pervious savings, which can affect the current time expenditure. Government expenditure is assumed to enter the model through the production activity, which also influences the consumption pattern. Introducing human capital into the model gives

$$
H C P_{t}=f\left(H C P_{t-1}, G O E_{t-1}\right)
$$

In equation 2.2, $\mathrm{HCP}$ is the human capital; GOE is government expenditure on human capital. For simplicity, it is assumed that aggregate consumption (AGCSP) depends solely on government expenditure, divided into productive expenditure and non-productive expenditure. The government expenditure on education and health are also captured in human capital formation. In this study, job training and other factors to improve skills embodied in human capital are ignored due to data unavailability. Incorporating equation 2.1 and 2.2 with the output model gives:

$$
O U T_{t}=A C A P^{\beta_{1}} L A B^{\beta_{2}} \mathrm{HCP}^{\beta_{3}} \mathrm{NPE}^{\beta_{4}}
$$

In equation 2.3, OUT is the aggregate output, ACAP is capital expenditure, LAB is labour, HCP is government expenditure on education and NPE is non-productive government expenditure, while $\beta_{1}, \ldots, \beta_{4}$ are the rates of growth in respective variables. The capital expenditure is further separated into two forms, as stated in Barro (1990) as follows:

$$
O U T_{t}=L A B^{\beta_{2}} \mathrm{HCP}^{\beta_{3}} \mathrm{NPE}^{\beta_{4}} A C A P 1^{\beta_{5}} A C A P 2^{\beta_{6}} P V I T^{\beta_{7}}
$$

In equation 2.4, ACAP1 includes the capital expenditure on the federal government, economic service, construction, transport and communication, which is unspecified as either productive expenditure or non-productive expenditure but regarded as 'functioning expenditure' in this study. NPE includes all the Federal Government recurrent expenditure in all sectors except health, and education expenditure referred to as non-productive government expenditure. LAB is aggregate employment. HCP comprises of both recurrent and capital expenditure on health and education. It is expected, in theory, that this expenditure will increase labour productivity (Popoola, Alege, Gershon \& Asaleye, 2019; Blanchard, 2010, Katema, 2000, Osborn, Haque \& Bose, 2003; Barro \& Sila - I- Martin, 1990) except non-productive expenditure which Barro (1990) hypothesised that it is accountable to lower aggregate growth in the long-run. ACAP2 is the capital expenditure on fixed assets referred to as government investment, and PVIT is private investment. Taking logarithm form of equation 2.4 becomes:

$$
O U T_{t}=\delta_{0}+\beta_{2} \operatorname{In} L A B+\beta_{3} \ln H C P+\beta_{4} \ln N P E+\beta_{5} \ln A C A P 1+\beta_{6} \ln A C A P 2+\beta_{7} \ln P V I T+\varepsilon_{t}
$$

In equation 2.5, a positive relationship is expected between the independent variables and dependent variable except for NPE. The work carries on preliminary tests of unit root and stationary properties on the series. The Augmented Dickey-Fuller (ADF), and Philips and Perron (PP) were used for the stationary test, while Johansen Cointegration was used to detect the number of cointegrating vectors among the series. The study indicates two cointegrating vectors, hence to achieve the study's objective, we normalised on output and employment variables.

Most of the time series data are normally not stationary at the level form, using such series may give a spurious result. Therefore, before regression analysis on time series variables, the check for stationarity is vital to avoid biased estimates or spurious results. In this study, we use both Augmented Dickey-Fuller (ADF) and Phillips Perron (PP) test to examine the presence of unit root (or non-stationarity) or otherwise. The ADF regression equation is given as: 


$$
\Delta Y_{t}=\lambda_{0}+\lambda_{1} \vartheta Y_{t-1}+\tau+\sum_{j=1}^{m} \vartheta_{j} \Delta Y_{t-k}+\varepsilon_{t}
$$

Where $\mathrm{Y}_{\mathrm{t}}$ is the time series, $\Delta$ is the first difference operator, $\tau$ is the linear trend, $\lambda_{0}$ is a constant and $\varepsilon_{t}$ is the error term. The null hypothesis of the existence of unit root is $\vartheta$ equals to 0 . The variables are differenced if the null hypothesis is rejected. Hence, the series could be integrated of order 1. After this, the study proceeds to test for cointegration among the series. Most series are integrated of order one I (1), if not stationary at level, that is, they have to be differenced once for them to be stationary. The ability to difference series once to make them stationary means that cointegration is likely to exist between the variables.

Likewise, the PP equation is given as:

$$
\Delta Y_{t}=(\psi-1) Y_{t-1}+v_{t}
$$

The PP follows the same outline with the ADF, with the same hypothesis carried out. The cointegration equation is given as:

$$
\Delta Y_{t}=\Omega_{0} K_{t}+\Psi Y_{t-1}+\sum_{q=1}^{p-1} \Omega_{q} \Delta Y_{q-p}+\omega_{t}
$$

In equation 3.8, $K_{t}$ expresses the vector deterministic of the series (OUT, LAB, HCP, NPE, ACAP1, ACAP2 and PVIT). $\Omega_{q}$ is the matrices showing the $\mathrm{m} * \mathrm{~N}$ of the series, while $\Psi$ is the matrices showing the cointegrating vectors. The error term is assumed to be $N_{m}(0, E)$.

Finally, the work examines the joint short and long-run causality using output and employment as dependent variables. This technique incorporates logically with the modelling approach outlined by Masih and Masih (1996). The restrictions are imposed on the independent variables, including the dependent variable's lags, excluding the constant or intercept. The tests are carried out if the variables are statistically different from zero. The long-run joint causality was examined from the VECM equations, from which the residual is taken to develop the error correction terms for each model. The short-run joint causality is examined using the WALD test statistics. Afterwards, the validity of the models was tested on the residuals. Residuals' series must not have serial correlation, must be homoscedastic, and normally distributed (Asaleye, Lawal, Popoola, Alege \& Oyetade, 2019; Asaleye Ogunrinola, Oloni \& Ogunjobi, 2017). This work applied Breusch Godfrey Serial Correlation Lagrange-Multiplier (LM) Test, Autoregressive Conditional Heteroskedasticity Test (ARCH) test and histogram normality test, which are presented in section 3. The stability of the models from the VECM was also tested, presented in the appendix section.

\begin{tabular}{|c|c|c|c|c|c|c|c|}
\hline \multicolumn{8}{|c|}{ Level Outcome } \\
\hline \multirow[t]{2}{*}{ Variables } & \multicolumn{3}{|c|}{ Augmented Dickey-Fuller (ADF) } & \multicolumn{4}{|c|}{ Phillip Perron (PP) } \\
\hline & $\mathbf{C}$ & $\mathbf{C} \& \mathbf{T}$ & $\mathbf{N}$ & $\mathbf{C}$ & $\mathbf{C} \& \mathbf{T}$ & $\mathbf{N}$ & $\mathbf{I}(\mathbf{D})$ \\
\hline OUT & 0.266979 & -1.977535 & 6.748344 & 0.147522 & -2.108808 & 5.602349 & - \\
\hline LAB & -1.619267 & -1.724218 & $2.195566^{*}$ & -1.577188 & -1.154206 & $2.214625^{*}$ & - \\
\hline $\mathrm{HCP}$ & -0.033738 & -2.612421 & 2.219509 & 0.600105 & -2.492653 & 5.724933 & - \\
\hline NPE & -0.068913 & -4.097174 & 4.569735 & 0.346910 & -1.097174 & 1.152562 & - \\
\hline ACAP1 & 0.346910 & -2.739255 & 2.988477 & 0.230805 & -1.597053 & 1.435497 & - \\
\hline ACAP2 & 0.613838 & -1.200057 & 1.341411 & 0.583324 & -1.241100 & 1.341411 & - \\
\hline PVIT & -0.107130 & -2.444947 & 0.807778 & -0.043423 & -1.459289 & 1.824350 & - \\
\hline \multicolumn{8}{|c|}{ First Difference Outcome } \\
\hline Variables & \multicolumn{3}{|c|}{ Augmented Dickey-Fuller (ADF) } & \multicolumn{3}{|c|}{ Phillip Perron (PP) } & $\mathbf{I}(\mathbf{D})$ \\
\hline
\end{tabular}

\section{Presentation of the Results}

Table 1. Outcome of the Stationary Result 


\begin{tabular}{|c|c|c|c|c|c|c|c|}
\hline OUT & $-4.459910^{* * * *}$ & $-4.386003^{* * *}$ & $-2.394572^{* *}$ & $-4.455371^{* * *}$ & $-4.381965^{* * *}$ & $-2.206995^{* *}$ & $\mathrm{I}(1)$ \\
\hline LAB & $-6.100023^{* * *}$ & $-5.831341^{* * *}$ & $-7.451330^{* * * *}$ & $-5.879483^{* * *}$ & $-5.637565^{* * *}$ & $-7.276946^{* * *}$ & $\mathrm{I}(1)$ \\
\hline $\mathrm{HCP}$ & $-7.229212^{* * * *}$ & $-7.190296^{* * * *}$ & $-6.001337^{* * * *}$ & $-7.454381^{* * * *}$ & $-8.747781^{* * *}$ & $-5.989749^{* * *}$ & $\mathrm{I}(1)$ \\
\hline NPE & $-8.258822^{* * * *}$ & $-8.092077^{* * * *}$ & $-2.407432^{* * * *}$ & $-9.142527^{* * *}$ & $-8.927832^{* * *}$ & $-5.421681^{* * *}$ & $\mathrm{I}(1)$ \\
\hline ACAP1 & $-6.227756^{* * *}$ & $-6.591858^{* * *}$ & $-7.064728^{* * * *}$ & $-8.517308^{* * *}$ & $-8.054360^{* * *}$ & $-6.921987^{* * *}$ & $\mathrm{I}(1)$ \\
\hline ACAP2 & $-4.321602^{* * * *}$ & $-4.588364^{* * * *}$ & $-3.086926^{* * *}$ & $-4.389008^{* * *}$ & $-4.516142^{* * *}$ & $-3.003688^{* * *}$ & $\mathrm{I}(1)$ \\
\hline PVIT & $-3.342844^{* *}$ & $-4.618210^{* * * *}$ & $-4.975631^{* * * *}$ & $-4.963847^{* * * *}$ & $-9.411036^{* * *}$ & $-4.955699^{* * *}$ & $\mathrm{I}(1)$ \\
\hline
\end{tabular}

Note: C, C\&T and $\mathrm{N}$ represent, constant, Constant and trend, and None respectively $* * *, * *$ and $*$ implies significance at 1 per cent, 5 per cent and 10 per cent respectively.

Table 1 shows the outcome of the stationarity result using ADF and PP. The results indicate that the series is not stationary at the level form using 5 per significance level. However, LAB that represents employment was stationary at a significant level of 10 per cent in level form. All the variables are stationary at 5 per cent significance level after the first difference. Although, most of the variables except OUT (with none) and PVIT (with constant) are stationary at the level of 1 per cent significance. In this study, we use 5 per significance level. Hence, all our variables are integrated of order 1. Against this background, we proceed to examine the long-run relationship among the series. The long-run relationship using the Johansen Cointegrating approach to determine the number of cointegrating vectors is presented in the appendix section. The result indicates that the Unrestricted Cointegration Rank Test Trace and Maximum Eigenvalue show two cointegrating vectors. Based on the outcome, the output and employment equations are established.

Table 2. Output and employment long-run equations' outcome

\begin{tabular}{cccccll}
\hline \multicolumn{2}{l}{ No of cointegrating Vector(s) } & \multicolumn{1}{c}{} & \multicolumn{1}{c}{$\mathbf{2}$} \\
\hline OUT & LAB & HCP & NPE & ACAP1 & ACAP2 & PVIT \\
\hline 1.000000 & $31.36409^{*}$ & $2.339152^{*}$ & $1.652542^{*}$ & $-3.872642^{*}$ & $1.750379^{*}$ & $-0.369578^{*}$ \\
& $(7.36285)$ & $(0.37043)$ & $(0.65422)$ & $(0.38734)$ & $(0.35519)$ & $(0.13445)$ \\
& {$[4.25978]$} & {$[6.31469]$} & {$[2.52597]$} & {$[-9.998043]$} & {$[4.92800]$} & {$[-2.74881]$} \\
\hline OUT & LAB & HCP & NPE & ACAP1 & ACAP2 & PVIT \\
\hline 0.000000 & 1.000000 & 0.027664 & $-0.161115^{*}$ & 0.032850 & -0.015279 & $0.015193^{*}$ \\
& & $(0.01702)$ & $(0.01114)$ & $(0.01748)$ & $(0.01128)$ & $(0.00499)$ \\
& & {$[1.62538]$} & {$[-14.4627]$} & {$[1.87929]$} & {$[-1.35452]$} & {$[3.04468]$} \\
\hline
\end{tabular}

* shows significant at the level of 5 per cent. ( ) shows the Standard errors while [ ] shows the t-statistics

Source: Author's Computation

Table 2 presents the output and employment of long-run equations. Given two cointegrating equations, there was normalisation on output in the first cointegrating equation and employment in the second cointegrating equation. Due to the normalisation process, the signs are reversed to enable proper interpretation. Similarly, Orden and Fisher (1993) noted that the vectors' regression coefficients are hard to interpret; therefore, this study's focus is on the signs of the coefficients.

In the output equation, aggregate employment (LAB), human capital expenditure (HCP), non-productive expenditure (NPE), functioning expenditure (ACAP1), government investment (ACAP2) and private investment (PVIT) are statistically significant at the level of 5 per cent. LAB, HCP, and ACAP2 are not economically significant. Government expenditure on human capital and function expenditure (capital expenditure on economic services, construction, transport and communication) negatively affects the output. These outcomes contradict the 'a prior expectations' of this study. Studies stressed that human capital development increases output (Chu, Holscher \& McCarthy, 2020; Popoola, Alege, Gershon \& Asaleye, 2019; Blanchard, 2010, Katema, 2000; Glumm \& Ravikummar, 1997). NPE, ACAP1 and PVIT are economically significant. The non-productive expenditure has a 
negative relationship with output; this is in line with Barro (1990) that stressed that unproductive government expenditure is likely to reduce aggregate growth in the economy. Government investment and private investment have a positive relationship with output; the outcome is in line with the study of Barro and Sila - I - Martin (1990) that posited positive relationship between investment and growth in the economy. The finding of this study with output and government productive expenditure contradicts Osborn, Haque and Bose (2003), who emphasised that productive government expenditure promotes growth.

In the employment equation, NPE and PVIT are statistically significant at the level of 5 per cent. The NPE has a positive relationship with employment, while PVIT has a negative impact on employment. The implication of this result shows that government expenditure on the non-productive channel has not improved the economy, although there is an increase in employment generation through this channel, which has not promoted broad-based growth, has evidence with a negative relationship between output and employment.

Table 3. Short and long-run joint causality for output and employment from VECM

\begin{tabular}{|c|c|c|c|c|}
\hline \multicolumn{5}{|c|}{ Output Long Run Joint Causality } \\
\hline $\begin{array}{l}\text { Coefficient } \\
\text { Value: C (1) }\end{array}$ & $\begin{array}{c}\text { No of Co-integrating } \\
\text { equation }(\mathrm{s})\end{array}$ & No of Lags & $\begin{array}{l}\text { Probability } \\
\text { Value }\end{array}$ & $\begin{array}{l}\text { Evaluation of } \\
\text { Null Hypothesis }\end{array}$ \\
\hline-0.037532 & 1 & 2 & 0.2892 & Accepted \\
\hline \multicolumn{5}{|c|}{ Output Short Run Joint Causality (Wald Test) } \\
\hline \multirow[t]{2}{*}{$\begin{array}{l}\text { Null Hypothesis } \\
\text { C (2): C (13) }=0\end{array}$} & Chi-Square Value & Df & $\begin{array}{l}\text { Probability } \\
\text { Value }\end{array}$ & $\begin{array}{l}\text { Evaluation of } \\
\text { Null Hypothesis }\end{array}$ \\
\hline & 13.32843 & 12 & 0.3456 & Accepted \\
\hline \multicolumn{5}{|c|}{ Employment Long Run Joint Causality } \\
\hline $\begin{array}{l}\text { Coefficient } \\
\text { Value: C (1) }\end{array}$ & $\begin{array}{c}\text { No of Co-integrating } \\
\text { equation(s) }\end{array}$ & No of Lags & $\begin{array}{c}\text { Probability } \\
\text { Value }\end{array}$ & $\begin{array}{l}\text { Evaluation of } \\
\text { Null Hypothesis }\end{array}$ \\
\hline-0.017647 & 1 & 2 & 0.0515 & Rejected \\
\hline \multicolumn{5}{|c|}{ Employment Short Run Joint Causality (Wald Test) } \\
\hline $\begin{array}{l}\text { Null Hypothesis } \\
\text { C (2): C (13) = 0 }\end{array}$ & Chi-Square Value & Df & $\begin{array}{c}\text { Probability } \\
\text { Value }\end{array}$ & $\begin{array}{l}\text { Evaluation of } \\
\text { Null Hypothesis }\end{array}$ \\
\hline & 20.36782 & 12 & 0.0504 & Rejected \\
\hline
\end{tabular}

Source: Authors' Computation

Table 3 shows the short and long-run joint causality for output and employment. Prior to the estimation of the joint and short-run causality, the number of the cointegrating vector(s) is determined using Johansen Cointegration. For the output equation, the study excludes employment. Likewise, for the employment equation, we exclude output. The outcome of the cointegration result indicates one cointegrating vector each for output and employment. The C (1) coefficient represents the long-run behaviour, to establish long-run joint causality, the coefficient must be negative, falls within the value of 0 and 1 , and must be statistically significant. For the output equation, the null hypothesis of no long-run joint causality was accepted at the level of 5 per cent significance. The WALD test statistics was employed to analyse the joint short-run causality. The coefficients are C (2) to C (13). We test if they are significantly different from zero to establish the joint short-run causality. Evidence from the result of the output equation indicates that the null hypothesis of no joint-run causality is accepted at the significance level of 5 per cent. For the employment equation, both the null hypotheses for joint short-run and joint long run are rejected at the significance level of 5 per cent. The implication of the result shows that the independent variables can be used collective to promote employment both in the short and long-run. 
Table 4. Outcome of the diagnostic checks for output and employment models

\section{Output Equation Residual Diagnostic Result}

\section{Histogram-Normality Test}

\begin{tabular}{llll}
\hline Jarque-Bera & 0.469860 & Probability & 0.795626 \\
\hline Serial Correlation LM Test & & & \\
\hline Obs.* R-squared & 2.398607 & Probability Chi-square & 0.1248 \\
\hline Heteroskedasticity Test & & & \\
\hline Obs.* R-squared & 4.7454488 & Probability Chi-square & 0.0932 \\
\hline
\end{tabular}

Employment Equation Residual Diagnostic Result

\begin{tabular}{llll}
\hline Histogram-Normality Test & & \\
\hline Jarque-Bera & 7.733126 & Probability & 0.00245 \\
\hline Serial Correlation LM Test & & & \\
\hline Obs.* R-squared & 4.914234 & Probability Chi-square & 0.0857 \\
\hline Heteroskedasticity Test & & & \\
\hline Obs.* R-squared & 0.008902 & Probability Chi-square & 0.9248 \\
\hline
\end{tabular}

Source: Authors' Computation

Table 4 presents the outcome of the residual diagnostic checks for output and employment equations. The result shows that the output equation satisfies all the procedures to validate if the model was specified correctly. The employment equation also satisfies the condition mentioned above; however, the normality test indicates that the error is not normally distributed. However, uncorrelated errors would be desirable, but they are not preconditions for the model's validity (Brown, Durbin \& Evans, 1975; Asaleye, Okodua, Oloni \& Ogunjobi, 2017). The stability diagnostics using the Ramsey RESET and CUSUM test are presented in the appendix. For both models, the CUSUM lines are within the upper and lower boundaries to validate the models' stability condition. Consequently, the VECM satisfies the stability condition since the companion matrix's eigenvalues fall inside the unit circle, (presented in the appendix section).

\section{Conclusion and Recommendation}

This study examines the effect of non-productive and productive government expenditure on output and employment in Nigeria. Based on the findings, government expenditure (non-productive and productive) has an adverse effect on the economy. Similarly, evidence from the result establishes that government investment in human capital development has a negative impact on economic growth in Nigeria; this shows that government expenditure needs to be properly channelled to promote growth and development. Likewise, a negative relationship between output and employment is also established in this study, which indicates that the Nigerian economy's growth rate is not sufficient to transform the economy into gainful employment. Private investment stimulates economic growth in this study; this means that increase in private investment is needed in Nigeria to overcome the shortage of capital and stimulate growth. In the employment equation, the non-productive expenditure has a positive relationship with employment, while private investment has a negative impact on employment. The implication of this result shows that government expenditure on the non-productive channel has not improved the economy, although there is an increase in employment generation through this channel, which has not promoted inclusive growth. 
Based on these observations, the study suggests the following recommendations: the need to evaluate government spending on social costs and benefits analysis. In this case, careful evaluation of government expenditures between consumption and capital spending has to be considered. A minimum level of public spending is needed to make capital expenditure effective. Funds allocation to consumption expenditure should not go beyond this minimum level. That is the level at which the social costs equal the social benefits. Likewise, public investment should be made to compliment 'augment private investment.' It is argued that a direct contribution of public investment to economic growth is not as high as the private investment; this is because in public investments political forces dominate decision-making, and decisions on expenditure made are not usually based on the increase in productivity of political interests. However, in private investments, demand and supply economic forces should guide the allocation of resources to where they are most productive. Theoretically that there is a threshold level of overall government expenditure that stimulates economic growth as high as possible. Below this threshold, the impact of government expenditure on economic growth may be lower and above; the impact is lesser than the optimal.

\section{References}

Adama, I. J., Asaleye, A. J., Oye, A. J., \& Ogunjobi, O. J. (2018). Agricultural Production in Rural Communities: Evidence from Nigeria. Journal of Environmental Management and Tourism, 3(27), Summer, 428-438.

Afonso, A., \& González-Alegre, J. (2011). Economic growth and budgetary components: a panel assessment for the EU. Empirical Economics, 41, 703-723.

Aremu, C., Abberton, M., Adebiyi, T., Asaleye, A. J., Inegbedion, H., Abolusoro, S., ... Dunsin, O. (2019). Selecting Yield and Nutritional Traits in Sphenostylis stenocarpa Landraces for Food Improvement. Recent Patents on Food, Nutrition \& Agriculture, 10, 00-00.

Aremu, C. O., Alhassan, E. A., Asaleye, A. J., Alori, E., Ige, S., \& Nayan, G. (2018). Effect of Varietal and Tillage Methods on Agronomic and Yield Characters of Rice (ORYLA SATIVA L). International Journal of Civil Engineering and Technology (IJCIET), 9(13), 590-600.

Asaleye, A. J., Lawal, A. I, Popoola, O., Alege, P. O., \& Oyetade, O. O. (2019). Financial Integration, Employment and Wages Nexus: Evidence from Nigeria. Montenegrin Journal of Economics, 15(1), 141-154. https://doi.org/10.14254/1800-5845/2019.15-1.11

Asaleye, A. J., Ogala, A. F., Aremu, C. O., Ogala, C. E., Lawal, A. I., Inegbedion, H., \& Popoola, O. (2019). Design and Implementation of Workers' Pension Verification System in Central Region of Nigeria. International Journal of Mechanical Engineering and Technology, 10(2), 127-136.

Asaleye, A. J., Alege, P. O., Lawal, A. I., Popoola, O., \& Ogundipe, A. A. (2020). Cash crops financing, agricultural performance and sustainability: evidence from Nigeria. African Journal of Economic and Management Studies. https://doi.org/10.1108/AJEMS-03-2019-0110

Asaleye, A. J., Okodua, H., Oloni, E. F., \& Ogunjobi, J. O. (2017). Trade Openness and Employment: Evidence from Nigeria. Journal of Applied Economic Sciences, 4(50), Summer, 1194-1209.

Asaleye, A. J., Olurinola, I., Oloni, E. F., \& Ogunjobi, O. (2017). Productivity growth, wages and employment nexus: Evidence from Nigeria. Journal of Applied Economic Sciences, 5(51), Fall, 1362-1376.

Barro, R., \& Sala-i-Martin, X. (1990). Public Finance in Models of Economic Growth. NBER Working Paper No. 3362.

Barro, R. J. (1990). Government spending in a simple model of endogenous growth. Journal of Political Economy, 98, S103-S125.

Blanchard, O. (2011). Macroeconomics (updated ed., 5th ed.). Boston: Pearson.

Brown, R. L., Durbin, J., \& Evans, J. M. (1975). Techniques for Testing the Constancy of Regression Relationships over Time. Journal of the Royal Statistical Society, Series B (Methodological), 37(2), 149-192.

Christie, T. (2012). The effect of government spending on economic growth: testing the non-linear hypothesis. Bulletin Economics Result, 66(2), 183-204.

Chu, T. T., Holscher, J., \& McCarthy, D. (2020). The impact of productive and non-productive government expenditure on economic growth: an empirical analysis in high-income versus low-to middle-income economies. Empirical Economics, 58, 2403-2430. https://doi.org/10.1007/s00181-018-1616-3

Cyrenne, P., \& Pandey, M. (2015). Fiscal equalisation, government expenditures and endogenous growth. 
International Tax and Public Finance, 22(2), 311-329.

Devarajan, S., Swaroop, V., \& Zou, H. (1996). The composition of public expenditure and economic growth. Journal Monetary Economics, 37(2), 313-344.

Diamond, P. A. (1965). National debt in a neoclassical growth model. American Economic Review, 55, 1126-1150.

Fashina, O. A., Asaleye, A. J., Ogunjobi, J. O., \& Lawal, A. I. (2018). Foreign aid, human capital and economic growth nexus: Evidence from Nigeria. Journal of International Studies, 11(2), 104-117. https://doi.org/10.14254/2071-8330.2018/11-2/8

Gemmell, N., Kneller, R., \& Sanz, I. (2016). Does the composition of government expenditure matter for long-run GDP levels?. Oxford Bulletin Economic Statistics, 78(4), 522-547.

Glomm, G., \& Ravikumar, B. (1992). Public versus private investment in human capital: Endogenous growth and income inequality. Journal of Political Economy, 100, 818-834.

Ketema, T. (2006). The Impact of Government Spending on Economic Growth: The Case of Ethiopia. Department of Economics, Addis Ababa University.

Masih, A., \& Masih, R. (1996). Energy Consumption, Real Income and Temporal Causality: Result from a multi-country Study based on cointegration and Error Correction Modelling Techniques. Energy Economics, 18, 165-183.

Moreno-Dodson, B. (2008). Assessing the Impact of Public Spending on Growth, An Empirical Analysis of Seven Fast-Growing Countries, Poverty Reduction and Economic Management Network. Policy Research Working Paper 4663, World Bank.

Oladipo, O. A., Iyoha, F., Fakile, A., Asaleye, A. J., \& Eluyela, D. F. (2019a). Tax revenue and agricultural performance: evidence from Nigeria. Problems and Perspectives in Management, 17(3), 342-349. https://doi.org/10.21511/ppm.17 (3).2019.27

Oladipo, O. A., Iyoha, F., Fakile, A., Asaleye, A. J., \& Eluyela, D. F. (2019b). Do Government Taxes have Implications on Manufacturing Sector Output? Evidence from Nigeria. Journal of Management Information and Decision Sciences, 22(3), 181-190.

Olopade, B. C., Okodua, H., Oladosun, M., \&Asaleye, J. A. (2019). Human capital and poverty reduction in OPEC member countries. Heliyon, 5. https://doi.org/10.1016/j.heliyon.2019.e02279

Orden, D., \& Fisher, L. A. (1993). Financial deregulation and the dynamics of money, prices, and output in New Zealand and Australia. Journal of Money, Credit and Banking, 25(2), 273-292.

Osborn, D. R., Haque, M. E., \& Bose, N. (2003). Public Expenditure and Economic Growth: A Disaggregated Analysis for Developing Countries. Retrieved from http://www.socialsciences.manchester.ac.uk

Popoola, O., Alege, P. O., Gershon, O., \& Asaleye, J. A. (2019). Human capital channels and productivity growth: Evidence from Nigeria. Economics and Sociology, 12(4), 59-73. https://doi.org/10.14254/2071-789X.2019/12-4/3

Popoola, O., Asaleye, A. J., \& Eluyela, D. F. (2018). Domestic Revenue Mobilisation and Agricultural Productivity: Evidence from Nigeria. Journal of Advanced Research in Law and Economics, 4(34), Summer, 1439-1450. https://doi.org/10.14505/jarle.v9.4(34).31

Romer, P. (1986). Increasing returns and long-run growth. Journal of Political Economy, 94, 1002-1037.

Solow, R. M. (1956). A Contribution to the Theory of Economic Growth. Quarterly Journal of Economics, 70, 65-94.

Swan, T. W. (1956). Economic Growth and Capital Accumulation. Economic Record, 32, 334-361.

Sweezey, D., \& McConaghy, R. (2011). Manufacturing Growth. Retrieved 24th June 2013, from www.BTI_Third_Way_Idea_Brief_Manufacturing_Growth 


\section{Appendix}

Table A1. Unrestricted Cointegration Rank Test Trace and Maximum Eigenvalue

Series: OUT LAB HCP NPE ACAP1 ACAP2 PVIT

Unrestricted Cointegration Rank Test (Trace)

\begin{tabular}{lllll}
\hline $\begin{array}{l}\text { Hypothesised } \\
\text { No. of CE(s) }\end{array}$ & Eigenvalue & Trace Statistic & $\begin{array}{l}0.05 \\
\text { Critical Value }\end{array}$ & Prob.** \\
\hline None * & 0.842396 & 165.3349 & 125.6154 & 0.0000 \\
\hline At most $1 *$ & 0.788943 & 106.2094 & 95.75366 & 0.0079 \\
\hline At most 2 & 0.518985 & 56.42945 & 69.81889 & 0.3609 \\
\hline At most 3 & 0.381557 & 33.01005 & 47.85613 & 0.5563 \\
\hline At most 4 & 0.267396 & 17.63247 & 29.79707 & 0.5933 \\
\hline At most 5 & 0.210916 & 7.675678 & 15.49471 & 0.5007 \\
\hline At most 6 & 0.002978 & 0.095435 & 3.841466 & 0.7574 \\
\hline
\end{tabular}

Trace test indicates 2 cointegrating eqn(s) at the 0.05 level

* denotes rejection of the hypothesis at the 0.05 level

**MacKinnon-Haug-Michelis (1999) p-values

\begin{tabular}{lllll}
\hline \multicolumn{4}{l}{ Unrestricted Cointegration Rank Test (Maximum Eigenvalue) } \\
\hline $\begin{array}{l}\text { Hypothesised } \\
\text { No. of CE(s) }\end{array}$ & Eigenvalue & $\begin{array}{l}\text { Max-Eigen } \\
\text { Statistic }\end{array}$ & $\begin{array}{l}0.05 \\
\text { Critical Value }\end{array}$ & Prob.** \\
\hline None * & 0.842396 & 59.12541 & 46.23142 & 0.0013 \\
\hline At most $1 *$ & 0.788943 & 49.78000 & 40.07757 & 0.0030 \\
\hline At most 2 & 0.518985 & 23.41940 & 33.87687 & 0.4986 \\
\hline At most 3 & 0.381557 & 15.37758 & 27.58434 & 0.7178 \\
\hline At most 4 & 0.267396 & 9.956787 & 21.13162 & 0.7487 \\
\hline At most 5 & 0.210916 & 7.580243 & 14.26460 & 0.4230 \\
\hline At most 6 & 0.002978 & 0.095435 & 3.841466 & 0.7574 \\
\hline $\begin{array}{l}\text { Max-eigenvalue test indicates 2 cointegrating eqn(s) at the } 0.05 \text { level } \\
\text { * denotes rejection of the hypothesis at the 0.05 level }\end{array}$ & & \\
**MacKinnon-Haug-Michelis (1999) p-values & & \\
\hline
\end{tabular}




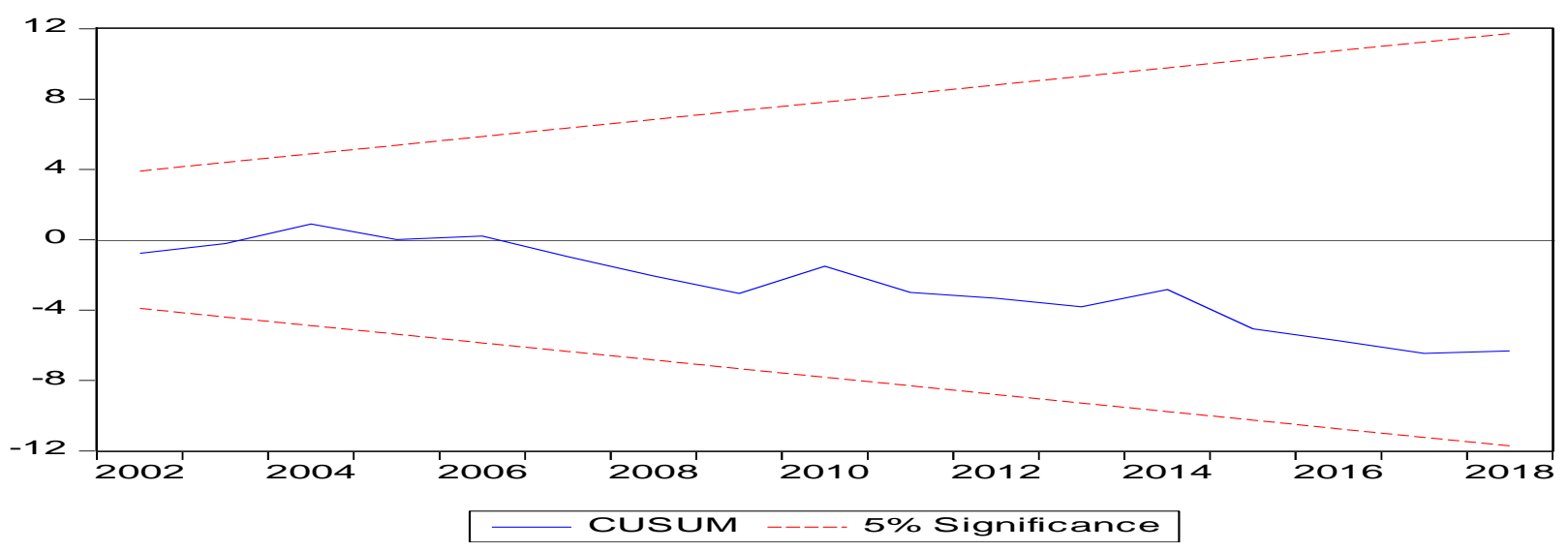

Figure 1A. Stability Diagnostic for Output Model

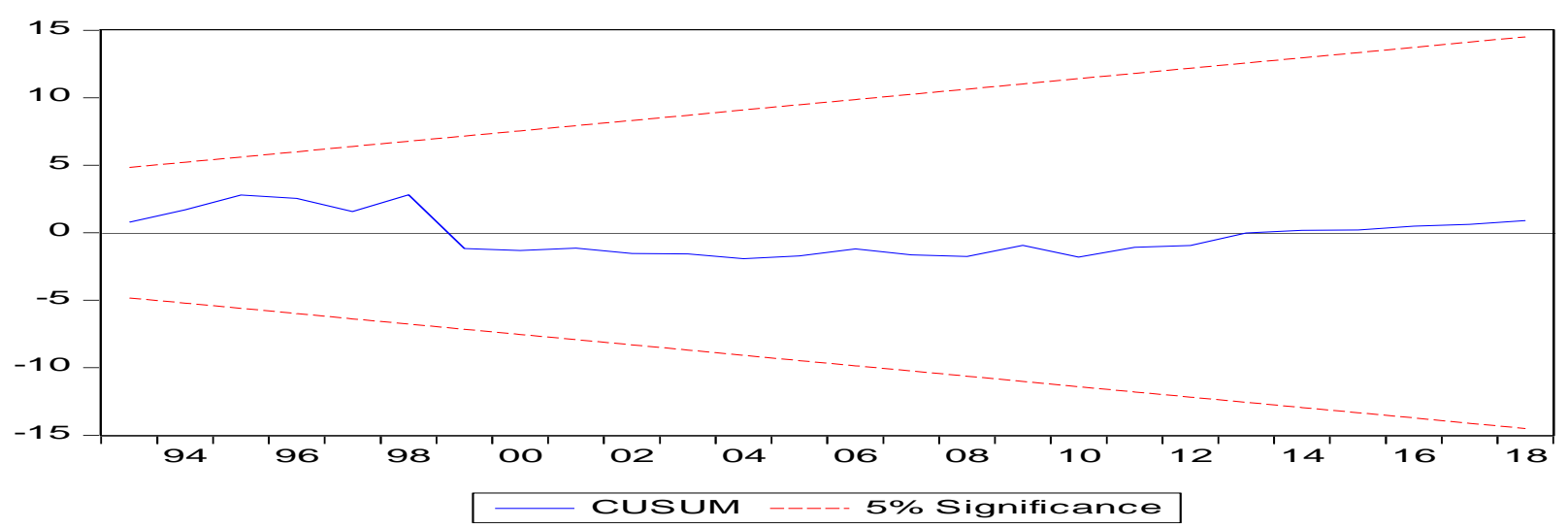

Figure 2A. Stability Diagnostic for Employment Model

Inverse Roots of AR Characteristic Polynomial

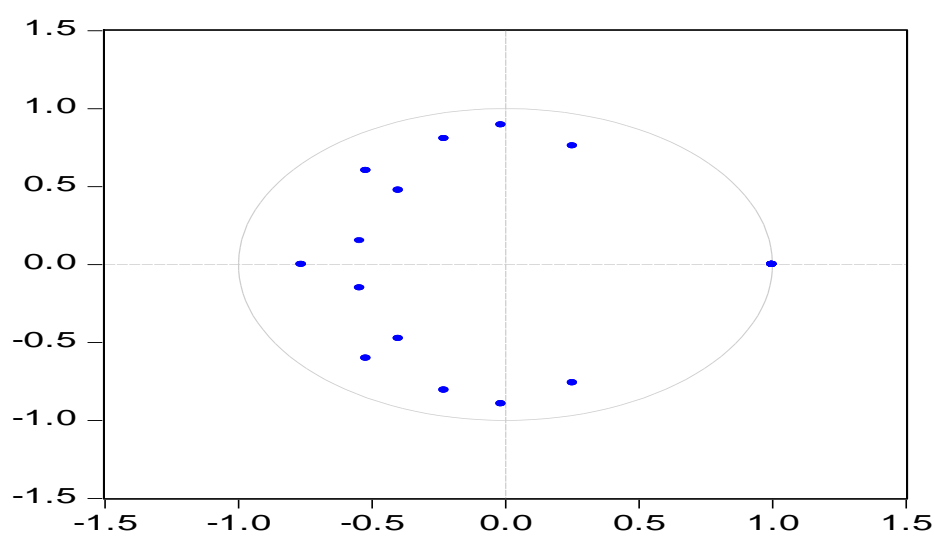

Figure 3A. Stability of System of equations for Output Model 
Inverse Roots of AR Characteristic Polynomial

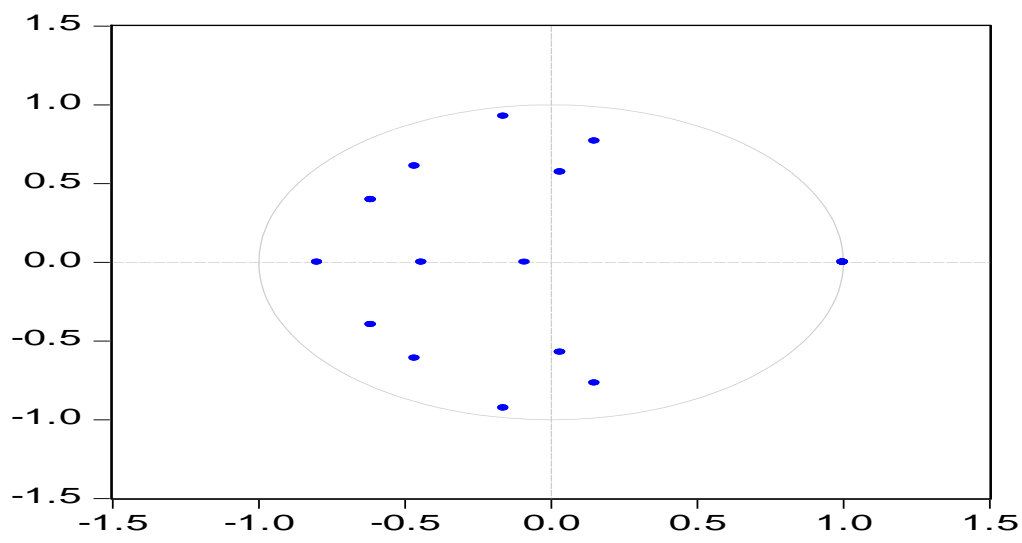

Figure 4A. Stability of System of equations for Output Model

\section{Copyrights}

Copyright for this article is retained by the author(s), with first publication rights granted to the journal.

This is an open-access article distributed under the terms and conditions of the Creative Commons Attribution license (http://creativecommons.org/licenses/by/4.0/). 